\title{
Assessment of learning powered mobility use-Applying grounded theory to occupational performance
}

\author{
Lisbeth Nilsson, PhD, OTR; ${ }^{*}$ Josephine Durkin, PhD, DipCOT $^{2}$ \\ ${ }^{1}$ Division of Occupational Therapy and Occupational Science, Department of Health Sciences, Lund University, Lund, \\ Sweden; ${ }^{2}$ Independent Researcher, East Sussex, United Kingdom
}

\begin{abstract}
Collaboration by two grounded theory researchers, who each had developed a learning continuum instrument, led to the emergence of a new tool for assessment of learning powered mobility use. We undertook a rigorous process of comparative reanalysis that included merging, modifying, and expanding our previous research findings. A new instrument together with its facilitating strategies emerged in the course of revisits to our existing rich account of data taken from real environment powered mobility practice over an extensive time period. Instrument descriptors, categories, phases, and stages allow a facilitator to assess actual phase and plot actual occupational performance and provide a learner with the just right challenge through the learning process. Facilitating strategies are described for each of the phases and provide directions for involvement during learner performance. The learning approach is led by a belief system that the intervention is user-led, working in partnership and empowering the learner. The new assessment tool is inclusive of every potential powered mobility user because it focuses on the whole continuum of the learning process of powered mobility use from novice to expert. The new tool was appraised by clinicians and has been used successfully in clinical practice in the United Kingdom and Sweden.
\end{abstract}

Key words: clinical assessment tool, coconstruction, cognitive disabilities, dialog, facilitation, instrument development, learning strategies, modification of theory, neurological rehabilitation, occupational performance, occupational therapy, partnership, powered wheelchair, tool use learning, user-led intervention.

\section{INTRODUCTION}

Powered mobility use is an area of occupational performance that develops as a result of practice [1]. Occupational performance is defined as "the ability to perceive, desire, recall, plan and carry out roles, routines, tasks and sub-tasks for the purpose of self-maintenance, productivity, leisure and rest in response to demands of the internal and/or external environment" [2]. Learning by experience provides "multifarious forms of interrelationships" [3]. Learning by doing in the situation is essential for the development and growth of the learner [4].

Butler et al. were the first to give some direction for powered mobility assessment by identifying seven criterion skills [5]. Traditionally, powered mobility instruments focus on skills and/or developmental domains and readiness for powered mobility provision [6-7]. As an example, the Pediatric Powered Wheelchair Screening Test was constructed from established developmental criteria and theoretical ideas and then validated with children with physical disabilities [8-9]. This instrument

\footnotetext{
Abbreviations: ALP $=$ Assessment of Learning Powered mobility use, GT = grounded theory.

*Address all correspondence to Lisbeth Nilsson, PhD, OTR; Box 158, SE-960 33 Murjek, Sweden; +46-976-20222. Email: lisbeth.nilsson@med.lu.se http://dx.doi.org/10.1682/JRRD.2013.11.0237
} 
assesses readiness for powered mobility and consists of 34 items across five Piagetian-based skill domains to predict powered wheelchair driving ability. Field stated the importance of having a multifaceted approach to provision of powered mobility and pointed out manifold aspects influencing an individual's performance on a powered wheelchair trial, such as human abilities, technology features, environmental conditions, and the setup of the driving assessment and practice [10]. Routhier et al. compiled and compared powered mobility assessment tools and accomplished a framework suggesting a more comprehensive view of assessing performance in a wheelchair [6]. Durkin focused on the need for the development of a child-led assessment tool for powered mobility learners; she stated that there is "a need to move away from an adult 'pass' or 'fail' perspective" and that "a reflective evaluative continuum of learning stance is the balance which is missing from existing data" [11].

Durkin's grounded theory (GT) research focused on discovering powered mobility skills with children with multiple and complex disabilities [11-13]. She collected video data from 11 typically developing children aged 6 mo to $5 \mathrm{yr}$ and 11 children with disabilities aged 5 to $17 \mathrm{yr}$; she also consulted with 7 children with disabilities as well as 21 prescribing clinicians. The work was carried out from 1999 to 2006. Durkin found three stages of learning, which she set in context to six levels of attention and a model of skill acquisition as part of being a responsive partner in learning. Durkin, in her dissertation, presented the Powered Mobility Assessment Tool [12].

Nilsson also carried out GT research [1,14-18]: her work focused on people with profound cognitive disabilities from several age groups. Nilsson studied what this population could achieve from practice in a powered wheelchair. She collected data from 45 participants who had profound cognitive disabilities with age of inclusion between $12 \mathrm{mo}$ and $52 \mathrm{yr}, 64$ participants who had other degrees of cognitive disabilities aged $16 \mathrm{mo}$ to $86 \mathrm{yr}$, and 17 typically developing infants aged 3 to 12 mo [17]. The work was carried out from 1993 to 2007. Nilsson identified an eight-phase learning process and an assessment tool-Eight Phases of Growing Consciousness of Joystick Use to Operate a Powered Wheelchair [16].

Durkin's clinical experience has been as a working occupational therapist for $30 \mathrm{yr}$ with adults and children with neurodisabilities in acute, community, and educational settings, all of which included assessment and powered mobility provision. Her postgraduate education includes, but is not limited to, training in neurodevelopment, sensory integration, intensive interaction, and the use of the Hanen program. Nilsson has gained $30 \mathrm{yr}$ of clinical experience with adults and children involving assessment and powered mobility provision before starting the studies of what people can achieve from practice in a powered wheelchair in 1994. Her continuing education covers, for example, neurodevelopment, language development, alternative and augmentative communication, developmental psychology, sensory integration, activity theory, and pedagogy.

Durkin and Nilsson both carried out their research with the learners/users in their real environment and both studies received ethical approval from their respective national organizations [12-13,16-17].

Livingstone contrasted the work of Durkin and Nilsson and the fact that they both focused on the continuum of learning rather than persisting to address prerequisite and cognitive skills within powered mobility use [19]. Hardy makes the point that "while clinicians endeavor to quantify skills necessary to operate a powered wheelchair it is likely that many skills previously considered 'prerequisites' for mobility are actually developmental achievements occurring as a consequence of mobility" [7].

Livingstone's work [19] connected the two of us, Durkin and Nilsson, which led us to agree to work as grounded theorists in partnership in order to further the development of our assessment tools for learning powered mobility use. The aim of our collaboration was to merge and modify our existing tools and further develop learning strategies.

\section{METHODS}

GT [20-22] was used to merge our previous research findings from both assessment tools. The constant comparative analytic process of GT involves selective coding, pattern seeking, writing memoranda, and sorting to the point of saturation, meaning the point where new data does not add to or change the emerging categories and their indicators. During the analytic process, it is important to stay open, which includes looking for more data to compare with, coding for new categories, and modifying the emerging theory. This methodology enabled us to reach a higher conceptual level by carrying out a structured process of reanalysis and consolidation. We both came with a rich account of collected, analyzed, and conceptualized data, together with independent findings and 
clinical experience. A number of different methods were used to collect the data we brought with us, including observational video, focus groups, interviews, field notes, and literature reviews. Further ethical approval for use of existing data sets for the reanalysis was not necessary because no new participant data were collected and the original consent forms addressed recording, storage, and scientific use of the video.

The steps we took in our analytic process were written up in an audit trail. Our initial research questions were as follows: What is the process of learning? What facilitates and what hinders the process? Which abilities are necessary? Is the learning process connected to providing technology and not viewed as therapeutic occupation in its own right by many? We started the process by comparing and exploring perspectives and standpoints and clarifying each other's theoretical frameworks and belief systems; this led to identifying common views and similarities in our separate works. In previous GT studies, Nilsson had identified a learning continuum consisting of eight phases and Durkin had identified six levels. We tested our existing assessment tools from multiple perspectives by viewing and assessing around a total of $40 \mathrm{~h}$ of each other's video data sets using our own and each other's instruments. The video data were used to illustrate behaviors, acts, and interaction and clarify distinctions in between phases in the learning process. The video data sets we used were Typically Developing Infants and Children (Durkin and Nilsson), Children with Disabilities (Durkin and Nilsson), and Adults with Disabilities (Nilsson). Our comparison of indicators and categories within each instrument led to the agreement of eight distinct phases that could be observed within the continuum of learning powered mobility use.

Then, we separated out the content of each instrument to allow the process of constant comparative analysis to begin and lead to a higher level of conceptualization. We revisited, resorted, and recategorized both sets of indicators until saturation was achieved. We also revisited our video data and the literature to assist the process of modification and expansion until the emergence of the new instrument Assessment of Learning Powered mobility use (ALP) was completed.

Having established a common frame of knowledge, we employed the same rigorous process to merge and further expand specific strategies facilitating learning in each of the eight phases of the continuum of learning. The starting point for the process was the new ALP instrument and the results presented in our previous works, which included Durkin's findings from her focus group with the children with disabilities [12] and Nilsson's descriptions of training strategies for each phase in the process of learning joystick use [16]. Effective strategies emerged from the knowledge we had developed during our extensive years of clinical practice and continuing education and through carrying out numerous sessions of powered mobility practice with a wide variety of learners during our respective studies. The emergence of the expansion and modification of the ALP facilitating strategies was supported by the reanalysis of video data where we cross-reviewed our recordings, intensely discoursed, and examined the effects of observed interplay between the learner and the facilitator. The video recordings allowed us to observe a variety of facilitators, together with both researchers independently acting as facilitators.

Clinicians in Sweden [23-24] and the United Kingdom used and appraised the new instrument together with the facilitating strategies, which resulted in us making minor changes to the organization of the categories and a few language modifications to the descriptors in the ALP.

The model of trustworthiness created by Lincoln and Guba [25] ensured rigor was achieved in our independent studies, and this model was also employed in our joint reanalysis and consolidation of the data, which led to the emergence of the ALP tool consisting of the ALP instrument and the ALP facilitating strategies.

\section{RESULTS}

Our constant comparative reanalysis of our existing data accounts led us to the discovery of the new ALP assessment tool. The ALP instrument assesses the learner's occupational performance in a powered wheelchair. The instrument consists of eight phases of learning, five categories of observation, and three stages of transition. Each phase and stage identified in the ALP instrument is connected to specific ALP strategies facilitating progress in the learning continuum. The ALP instrument is presented in the Table (also presented as Appendix 1, available online only) and the facilitating strategies can be found in Appendix 2 (available online only).

\section{ALP Instrument}

The eight phases in the learning process range from one to eight (novice to expert). From phase 1 (novice) and 
JRRD, Volume 51, Number 6, 2014

Table.

Assessment of Learning Powered mobility use instrument, version 2.0.

\begin{tabular}{|c|c|c|c|c|c|c|}
\hline Phase & Attention & $\begin{array}{l}\text { Activity and } \\
\text { Movement }\end{array}$ & $\begin{array}{c}\text { Understanding } \\
\text { of Tool Use }\end{array}$ & $\begin{array}{c}\text { Expressions and } \\
\text { Emotions }\end{array}$ & $\begin{array}{l}\text { Interaction and } \\
\text { Communication }\end{array}$ & Stage \\
\hline 8: Expert & $\begin{array}{l}\text { Attention well estab- } \\
\text { lished and sustained. } \\
\text { Relaxed, active, not } \\
\text { tense. }\end{array}$ & $\begin{array}{l}\text { Occupation, com- } \\
\text { posed of two or } \\
\text { more activities } \\
\text { Fluid, smooth, and } \\
\text { precise movements. } \\
\text { Driving is automatic. } \\
\text { A means for doing } \\
\text { other activities in } \\
\text { multiple settings. } \\
\text { Intuitively organizes } \\
\text { and understands the } \\
\text { task they are } \\
\text { encountering. } \\
\text { Knows what to do } \\
\text { based on mature } \\
\text { and practiced } \\
\text { understanding. }\end{array}$ & $\begin{array}{l}\text { Integrated Tool Use } \\
\text { Consciousness is } \\
\text { focused on the other } \\
\text { parts of the } \\
\text { occupation. } \\
\text { Driving more or less } \\
\text { subconscious. } \\
\text { Consistent precision } \\
\text { control of powered } \\
\text { wheelchair. } \\
\text { Consciously deliber- } \\
\text { ates a situation and } \\
\text { performs their own } \\
\text { judgment of how to } \\
\text { resolve the situation. } \\
\text { Takes care of others } \\
\text { while driving pow- } \\
\text { ered wheelchair. }\end{array}$ & $\begin{array}{l}\text { Dependent on the } \\
\text { doing of "other" } \\
\text { activities }\end{array}$ & $\begin{array}{l}\text { Multilevel Inte- } \\
\text { grated Interaction } \\
\text { Is able to interact with } \\
\text { the machine, interact } \\
\text { with the environ- } \\
\text { ment, and interact } \\
\text { with social partners. }\end{array}$ & $\begin{array}{l}\text { Explore Perfor- } \\
\text { mance: Extrovert } \\
\text { stage-focus body, } \\
\text { machine, environ- } \\
\text { ment and occupation. }\end{array}$ \\
\hline 7: Proficient & $\begin{array}{l}\text { Multichanneled } \\
\text { attention. } \\
\text { Generally focused. }\end{array}$ & $\begin{array}{l}\text { Occupation for its } \\
\text { own sake } \\
\text { Refinement of graded, } \\
\text { timed movements. } \\
\text { Driving for the sheer } \\
\text { pleasure of driving. } \\
\text { Navigating within the } \\
\text { physical space. }\end{array}$ & $\begin{array}{l}\text { Fluent Precise Use of } \\
\text { Tool } \\
\text { Aware of conse- } \\
\text { quences and con- } \\
\text { scious of how to } \\
\text { control the steering } \\
\text { with the joystick. } \\
\text { Refining maneuver- } \\
\text { ing skills to fluent } \\
\text { use. } \\
\text { Takes care of them- } \\
\text { selves within the } \\
\text { powered wheelchair. }\end{array}$ & $\begin{array}{l}\text { Happiness } \\
\text { Satisfaction }\end{array}$ & $\begin{array}{l}\text { Concurrent } \\
\text { Interactions } \\
\text { Openness to multilevel } \\
\text { interactions - displays } \\
\text { readiness to interact at } \\
\text { more than one level. } \\
\text { No longer easily inter- } \\
\text { rupted by occurrences. } \\
\text { Interacting with the } \\
\text { machine in a playful } \\
\text { way. Contrives interac- } \\
\text { tions within the social } \\
\text { space. }\end{array}$ & \\
\hline 6: Competent & $\begin{array}{l}\text { Multichanneled atten- } \\
\text { tion but easily } \\
\text { disrupted. } \\
\text { Focused on using the } \\
\text { tool goal directed. }\end{array}$ & $\begin{array}{l}\text { Activity } \\
\text { Controlled but unre- } \\
\text { fined movements. } \\
\text { Able to coarsely steer } \\
\text { in a desired } \\
\text { direction. } \\
\text { Concentrating on get- } \\
\text { ting from A to B. } \\
\text { Often ignores the } \\
\text { environment and } \\
\text { people around them. }\end{array}$ & $\begin{array}{l}\text { Competent Use of } \\
\text { Tool } \\
\text { Conscious of the need } \\
\text { for sequencing of the } \\
\text { acts in a certain order } \\
\text { to reach a desired } \\
\text { point or place. } \\
\text { Controlled but coarse } \\
\text { use of the tool. } \\
\text { Regression to use } \\
\text { body movements } \\
\text { instead of tool use- } \\
\text { using arm or foot to } \\
\text { push away from } \\
\text { obstacle. }\end{array}$ & $\begin{array}{l}\text { Serious } \\
\text { Content } \\
\text { Laugh } \\
\text { Excited }\end{array}$ & $\begin{array}{l}\text { Consecutive } \\
\text { Interactions } \\
\text { One level interactions } \\
\text { occur one after the } \\
\text { other: interaction with } \\
\text { the machine has to } \\
\text { stop because of dis- } \\
\text { ruptive occurrences. }\end{array}$ & \\
\hline $\begin{array}{l}\text { 5: Sophisticated } \\
\text { Beginner }\end{array}$ & $\begin{array}{l}\text { Two-channeled } \\
\text { attention. } \\
\text { Active, concentrated. }\end{array}$ & $\begin{array}{l}\text { Sequences of chains } \\
\text { of acts } \\
\text { Intentional more eager } \\
\text { or violent movements. } \\
\text { Exploring the } \\
\text { machine. } \\
\text { Experimenting with } \\
\text { steering by compos- } \\
\text { ing effects in differ- } \\
\text { ent patterns. } \\
\text { Experimenting to find } \\
\text { the pattern of the tool. }\end{array}$ & $\begin{array}{l}\text { Idea of Competent } \\
\text { Use is Born } \\
\text { Conscious of the abil- } \\
\text { ity to cause many dif- } \\
\text { ferent effects, motion } \\
\text { in different direc- } \\
\text { tions. Searching the } \\
\text { steering pattern. } \\
\text { Understands the use of } \\
\text { electronic mobility } \\
\text { guidance systems. }\end{array}$ & $\begin{array}{l}\text { Eager } \\
\text { Smile } \\
\text { Serious } \\
\text { Frustration } \\
\text { Periods of frustration. } \\
\text { Knowing possibili- } \\
\text { ties but not achieving } \\
\text { desired tool use } \\
\text { goals. } \\
\text { Periods of blocking } \\
\text { intertwined with short } \\
\text { peaks of success. }\end{array}$ & $\begin{array}{l}\text { Reciprocated } \\
\text { Interaction } \\
\text { Directs attention by } \\
\text { pointing to convey a } \\
\text { message that } \\
\text { requires the play- } \\
\text { mate to respond. } \\
\text { Triadic Interaction } \\
\text { Interaction with a per- } \\
\text { son on a third part- } \\
\text { a person, an object, } \\
\text { or something else in } \\
\text { the environment. }\end{array}$ & $\begin{array}{l}\text { Explore Sequencing: } \\
\text { Difficult transition- } \\
\text { focus body, machine } \\
\text { and environment. }\end{array}$ \\
\hline
\end{tabular}


Table. (cont)

Assessment of Learning Powered mobility use instrument, version 2.0.

\begin{tabular}{|c|c|c|c|c|c|c|}
\hline Phase & Attention & $\begin{array}{l}\text { Activity and } \\
\text { Movement }\end{array}$ & $\begin{array}{c}\text { Understanding } \\
\text { of Tool Use }\end{array}$ & $\begin{array}{c}\text { Expressions and } \\
\text { Emotions }\end{array}$ & $\begin{array}{l}\text { Interaction and } \\
\text { Communication }\end{array}$ & Stage \\
\hline $\begin{array}{l}\text { 4: Advanced } \\
\text { Beginner }\end{array}$ & $\begin{array}{l}\text { Single-channeled } \\
\text { attention but able to } \\
\text { shift spontaneously. } \\
\text { Attentive. }\end{array}$ & $\begin{array}{l}\text { Chain of acts } \\
\text { Intentional but } \\
\text { cautious, careful } \\
\text { movements. } \\
\text { Exploring the } \\
\text { joystick. } \\
\text { Explorations of differ- } \\
\text { ent effects - drive, } \\
\text { stop. Testing out } \\
\text { different grips. } \\
\text { Able to press a single } \\
\text { switch, hold, and } \\
\text { release }\end{array}$ & $\begin{array}{l}\text { Exploration of } \\
\text { Extended Use } \\
\text { Conscious of more } \\
\text { than one effect. } \\
\text { Motion in different } \\
\text { directions depend- } \\
\text { ing on how acts are } \\
\text { combined. } \\
\text { Exploring the conse- } \\
\text { quences of activating } \\
\text { the tool. } \\
\text { Understands } 2 \\
\text { switches have differ- } \\
\text { ent functions. }\end{array}$ & $\begin{array}{l}\text { Serious } \\
\text { Smile } \\
\text { Sometimes Laugh } \\
\text { Exhibits a desire to } \\
\text { explore beyond the } \\
\text { world of their tray. } \\
\text { Shift focus in between } \\
\text { near and far. }\end{array}$ & $\begin{array}{l}\text { Mutual Interaction } \\
\text { Requests the attention } \\
\text { of the playmate by } \\
\text { pointing at objects or } \\
\text { events in their close } \\
\text { vicinity. }\end{array}$ & \\
\hline 3: Beginner & $\begin{array}{l}\text { Single-channeled } \\
\text { attention but able to } \\
\text { shift attention. } \\
\text { Alert. }\end{array}$ & $\begin{array}{l}\text { Act } \\
\text { Distinct targeted } \\
\text { movements. } \\
\text { Activates joystick to } \\
\text { get the effect of } \\
\text { motion. } \\
\text { Applying force. } \\
\text { Able to press a single } \\
\text { switch. }\end{array}$ & $\begin{array}{l}\text { Basic Use } \\
\text { Conscious of how one } \\
\text { act can cause one } \\
\text { effect. Act starts } \\
\text { motion. } \\
\text { Change position } \\
\text { within the room, e.g., } \\
\text { circling. Regression } \\
\text { to using body move- } \\
\text { ments to try and } \\
\text { move the machine. }\end{array}$ & $\begin{array}{l}\text { Serious } \\
\text { Contented } \\
\text { Smile }\end{array}$ & $\begin{array}{l}\text { Initiates Interaction } \\
\text { Keeps or responds to } \\
\text { eye-contact. } \\
\text { Facial signaling. }\end{array}$ & $\begin{array}{l}\text { Explore Functions: } \\
\text { Introvert stage - focus } \\
\text { body and machine. }\end{array}$ \\
\hline 2: Curious Novice & $\begin{array}{l}\text { Single-channeled. } \\
\text { At times more alert. } \\
\text { Passive. }\end{array}$ & $\begin{array}{l}\text { Pre-Act } \\
\text { Diffuse vague multidi- } \\
\text { rected movements. } \\
\text { Touches or hits differ- } \\
\text { ent parts of the chair } \\
\text { in between sitting } \\
\text { still. } \\
\text { Touches or hits a } \\
\text { switch-experiment- } \\
\text { ing with exerting a } \\
\text { force. }\end{array}$ & $\begin{array}{l}\text { Idea of Basic Use is } \\
\text { Born } \\
\text { Preconscious of how a } \\
\text { self-initiated act can } \\
\text { cause the effect of } \\
\text { setting the chair in } \\
\text { motion. }\end{array}$ & $\begin{array}{l}\text { Contented } \\
\text { Curious } \\
\text { Anxious } \\
\text { Angry }\end{array}$ & $\begin{array}{l}\text { Responds to } \\
\text { Interaction } \\
\text { Gets in eye-contact. } \\
\text { Physical contact. } \\
\text { Behavioral mirroring. } \\
\text { Joint focusing on } \\
\text { activity. }\end{array}$ & \\
\hline 1: Novice & $\begin{array}{l}\text { Extreme distractibility. } \\
\text { No response to interac- } \\
\text { tion (focus on the } \\
\text { novel tool or novel } \\
\text { situation). } \\
\text { Passive or anxious. }\end{array}$ & $\begin{array}{l}\text { Excited } \\
\text { Interested in looking } \\
\text { at and touching the } \\
\text { tool. } \\
\text { Non-Act } \\
\text { No specific intentional } \\
\text { movements. } \\
\text { May accidentally acti- } \\
\text { vate the joystick. Is } \\
\text { still for long periods. } \\
\text { Protective withdrawal } \\
\text { body language. } \\
\text { Rejection } \\
\text { Displays stereotyped } \\
\text { or rejecting behav- } \\
\text { iors, wanting to get } \\
\text { out of the powered } \\
\text { wheelchair. }\end{array}$ & $\begin{array}{l}\text { No or Vague Idea of } \\
\text { Use } \\
\text { No or very limited } \\
\text { consciousness of } \\
\text { how own activity can } \\
\text { cause an effect. }\end{array}$ & $\begin{array}{l}\text { Open } \\
\text { Shows joy in } \\
\text { experiencing } \\
\text { guided motion. } \\
\text { Neutral } \\
\text { Displays minimal } \\
\text { facial expressions. } \\
\text { Whole body displays } \\
\text { motionlessness. } \\
\text { Anxiety } \\
\text { Worry, fear, annoy- } \\
\text { ance, crying. }\end{array}$ & $\begin{array}{l}\text { No Response } \\
\text { May be aware of oth- } \\
\text { ers attention. } \\
\text { Perceptive. } \\
\text { Physical proximity- } \\
\text { close in, draw back. } \\
\text { Avoidance } \\
\text { Avoidance of touch } \\
\text { from social partner. } \\
\text { No wish for interaction. } \\
\text { Wants to get rid of the } \\
\text { social partner. }\end{array}$ & \\
\hline
\end{tabular}

phase 2 (curious novice) to phase 3 (beginner), the learners are observed as being within a more introvert stage and need time and understanding to explore functions.
From phase 4 (advanced beginner) to phase 5 (sophisticated beginner), the learners have entered the difficult transition stage of exploring sequencing of functions. 
They can be eager but will often display frustration because they have reached the point where they understand what they can and want to do but are not always able to achieve what they desire.

The later phases, phase 6 (competent) and phase 7 (proficient) to phase 8 (expert), see the learners entering the extrovert stage of exploring performance. The learners in these phases are beginning to develop and demonstrate higher cognitive functions of goal-directed powered mobility performance, problem solving, and judgment.

The observational category of "level of attention" focuses on signs of attention regulation. "Activity and movement" focuses on motor control and motor performance. "Understanding of tool use" is the primary observable cognitive component. "Expression and emotions" give signs of motivation. "Interaction and communication" addresses social interplay. Each category contains detailed descriptors for each of the eight phases in the learning process.

\section{Facilitating Strategies}

We embraced the following belief system: to be user led, to work in partnership, and to empower the learner. The strategies have been divided and described under the different phases and stages in the learning process (Appendix 2).

The strategies for the early stage "explore functions" (body and machine) require the facilitating partner to be quiet and vigilant and pay very close attention to a slowpace activity. The facilitator approach at this stage requires patience, endurance, appropriate pacing of interaction, and setting up a suitable learning situation. The learner is allowed to become comfortable with the situation in order to begin the process of exploring functions.

During the stage "explore sequencing" (body, machine, and environment), the learner is able to achieve chains of acts and is exhibiting the desire to explore beyond the world of his or her own wheelchair lap tray. The emphasis for the learner is on building patterns on how the tool works. The facilitator approach is to allow trial and error and involve the learner in the process of reflecting on outcomes.

In the later stage "explore performance" (body, machine, environment, and occupation), the facilitator approach is to address the tempo of intervention; additional speed will need to be introduced to challenge and keep the learner motivated. Achievements are proved in increasingly complex environments. The learner is pro- vided with opportunities to integrate tool use in everyday occupation.

\section{DISCUSSION}

The ALP tool is an assessment tool that originated from two separate GT studies, both focused on discovering the process of learning powered mobility $[1,11-18]$. The ALP tool is grounded in extensive data taken from a number of sources including a wide group of participants over an extensive period of time. The ALP tool consists of the ALP instrument (Table) and the facilitating strategies (Appendix 2) and emerged as a result of merging, modifying, and expanding both sets of findings from each study. An intensive and detailed analysis of video data was used to validate the ALP instrument and to consolidate a set of facilitating learning strategies.

\section{ALP Tool in Practice}

The ALP instrument is used to identify the actual phase in the process of learning powered mobility use and analyze the occupational performance of the learner. Knowledge of actual phase assists the facilitator in choosing ALP facilitating strategies that provide the learner with appropriate challenges [26-27]. The learner's performance can then be compared over time. Progress can be plotted and continuing direction for ongoing involvement with the learner identified. The ALP instrument can be used to assess the early learning process rather than the prerequisites for safe powered mobility use and can therefore be used with infants and individuals with profound cognitive difficulties [17].

The learning sessions are dynamic and of the moment and therefore coconstructed with the learner [12,15,28]. The ALP facilitating strategies are used to emphasize development of the partnership between the facilitator and the learner [13,16-17]. An important role of the facilitator, when working in partnership with the learner, is to create a permissive atmosphere. Establishing trust, discovering a working dialog, understanding what motivates the learner, and enabling the optimum development of autonomy at each phase are important [12-13,16-17]. Gaining autonomy during each phase is necessary for progression through the whole learning continuum.

The facilitator has to be constantly vigilant, adjusting the level of facilitation to the learners oscillating progress [17] in order to keep providing the "just right challenge" 
[26-27] for the learner. Part of the partnership dialog is to encourage, guide, and evaluate their performance; carry out risk assessments; and modify the environment together as part of this dynamic learning process [13,17,29-31].

\section{Nature of ALP Instrument}

One of the primary features of the ALP instrument is that it assesses the occupational performance of the individual that covers more than the individual's cognitive domains and skills as part of the powered mobility learning process $[12,16]$. The descriptors within each of the five observational categories - level of attention, activity and movement, understanding of tool use, expressions and emotions, and interaction and communication-are unique and have emerged from rigorous analysis of occupational performance in the powered wheelchair.

The ALP instrument covers the early stage of exploring functions of the powered vehicle and the middle stage of exploring sequencing (where there is a difficult transition for the learner) and also provides a detailed assessment of the later stage where the learner is exploring use of the powered vehicle in a variety of environments. The instrument takes into account all the different learner groups and categories of factors that influence poweredwheelchair mobility $[6,12,16]$. The ALP instrument is independent of previous experience, environment, culture, age, and physical or cognitive development of the learner. The ALP instrument assesses the actual occupational performance and situation, can be carried out in a real environment, and is free of context dependents $[4,6]$.

The ALP instrument provides the facilitator with a marker of where the learner is within the whole process of learning. The learner may display components from more than one of the phases during a session. Progression of learning is an oscillating process [16-17]. The ALP instrument allows the facilitator to plot the oscillation between the phases during a session in order to gain an understanding of the effects of an individual's health status, level of energy, and position within the learning process [16-17]. Each individual has his or her own learning dynamic and will demonstrate his or her own unique learning pattern.

The ALP instrument offers an indication for intervention since it is coupled with ALP facilitating strategies for each of the phases in the learning process. The instrument can be used to assist decisions such as when is it appropriate to address the learner's frustration from elongated efforts of using equipment that consistently fail them by introducing additional electronic mobility guidance systems [32] - for example, the track guidance system or the sensor collision avoidance device - or review methods of access. The ALP instrument can be used with any powered mobility vehicle and associated accessories.

The ALP instrument presents the learner, family, and professionals with a common descriptive language for powered-mobility learning. It can therefore be used to form the basis of formal reports as well as being part of clinical documentation. The descriptors, categories, phases, and stages have credibility, transferability, dependability, and confirmability because they are grounded in data [33-34].

\section{HOW ALP TOOL MOVES AWAY FROM OTHER POWERED MOBILITY ASSESSMENTS}

The ALP tool meets the needs of all learners because it embraces the whole learning continuum of powered mobility from novice to expert and is grounded in data. It describes and includes the very early stages of learning and has therefore redrawn previously set boundaries that discriminate against certain groups of learners.

The ALP tool can be used with children or adults of any population who have profound cognitive disabilities, are at an early developmental level, or have typical cognitive abilities. It can be used from the phase of being a novice not understanding what the powered chair can be used for to the phase of being an expert performing skilled and safe navigation in any environment. Most other assessment tools require that the learner starts with the understanding that the vehicle can be set in motion with a steering device such as a joystick or single switch.

The ALP tool has a learning approach; the focus is to assess the learner's actual position in the process of learning powered mobility use. The ALP facilitating strategies are grounded by thick, rich descriptors to enable appropriate facilitation. The ALP instrument is not about "pass" or "fail" [11] or scoring individual prerequisite skills [8-9]; rather, it is about recognizing how well-attuned practice can develop the abilities necessary for skilled and safe driving [7].

The ALP instrument is used to assess actual occupational performance in the powered wheelchair in the real world. The focus is on the learner's occupational performance in a real situation and a holistic view of the practice situation is embraced, in contrast to a reductionist 
view involving assessment of prerequisite skills and specific tasks in a "test" or laboratory environment.

The ALP instrument and the facilitating strategies center attention to the necessity of a dialogic and mutual interaction and communication during the intervention. The ALP assesses the learners' occupational performance in relation to their expanding ability to attend to and process sensory input as well as their ability to multitask, which is observed in changes in their use of body, machine, environment, and occupation. Emphasis of the facilitating strategies is placed on the importance of the intervention to be user-led, playful, enticing, and motivating for the learner.

Taking into account that the ALP tool covers the whole continuum of the learning process, we view the practice in a powered wheelchair as being a therapeutic occupation in its own right. Many learners may not need to be powered mobility users as a final outcome of undertaking practice in a powered wheelchair. Ambulant individuals can also benefit from the therapeutic occupation of powered mobility use as a means to gain tool use experience in order to assist with their development or reestablishment of higher executive cognitive competencies.

\section{Trustworthiness of ALP Tool}

Livingstone, in her critical review of our research on powered mobility, proposed examination of psychometric properties of our previous instruments [19]. Psychometric testing of the ALP instrument's categories and descriptors with respect to validity is not relevant because they are grounded in observational data from powered wheelchair use in real life and not created through task analysis, while psychometric testing with respect to reliability and responsiveness to change are relevant because the ALP instrument is used to assess an individual's actual phase in the learning continuum and is based on observations of actual occupational performance. Focus for using the ALP tool is to understand where the learner is in the process and provide appropriate facilitation in addition to recognizing changes and achievements. The interrater reliability study of Nilsson et al.'s previous eight-phase assessment tool [18] showed a very good weighted kappa value (0.85), and that tool also showed responsiveness to change when it was used to assess the outcome of her 45 powered wheelchair learners with profound cognitive disabilities [1]. A study of the intra- and interrater reliability of the ALP instrument, as well as of its responsiveness to change, would strengthen the scientific evidence of its use in clinical practice.
Credibility was achieved because we both brought prolonged and varied field experience to this reanalysis of data to a higher conceptual level. The data were collected over an extensive time period and the video material was diverse (age, culture, environmental contexts, and cognitive level). The video data provided observational material from real situations. Reflexivity was established through comparing our belief systems and theoretical frameworks, as well as visiting new literature. Modifying and extending the emerging instrument was focused and intensive since it was carried out over an isolated and uninterrupted period of $3 \mathrm{wk}$. We both had established authority as independent GT researchers in the field of powered mobility and had each discovered a theory. Triangulation was ensured because we had collected data from the informants, their relatives, and professionals. Different data methods were used: observational video (with different groups and in diverse settings), focus groups, interviews, field notes, and literature review. For the theoretical triangulation, we visited the literature from the fields of psychology, pedagogy, cognition, sociology, and theories of motor control and activity.

Transferability was assured through data being taken from a variety of diverse populations, including level of motor and cognitive function, age, and typically developing children from both the United Kingdom and Sweden.

We revisited our dense descriptions as part of carrying out our peer examination together with the decoding and recoding of the data. Dependability was achieved by ensuring the establishment of a clear audit trail and carrying out a stepwise clarification technique with each other's video data as part of the critical discourse of each other's instruments, which led to the emergence of the new assessment tool.

As independent GT researchers, each of us arrived at similar conclusions from our own initial data. The newly constructed assessment tool was utilized and found applicable in clinical practice, which ensured confirmability in both countries. In compiling the new assessment tool, every interpretation came from at least two different data sources.

\section{CONCLUSIONS}

The ALP instrument, encompassing the ALP together with ALP facilitating strategies for learning, emerged as a result of the collaboration between the two GT researchers, Durkin and Nilsson. A rigorous analytical GT process 
involving merging, modifying, and expanding our previous research findings, including two tools for assessing powered mobility, led to the emergence of a new strengthened assessment tool. The ALP was successfully used and appraised in the clinical setting both in the United Kingdom and Sweden.

The ALP is the first powered mobility instrument to analyze the user-led occupational performance of the learner in a powered wheelchair using the observational categories of "level of attention," "activity and movement," "understanding of tool use," "expressions and emotions," "interaction and communication," and their descriptors. The ALP instrument is structured in phases and stages comprising the process of learning powered mobility use from novice to expert. The ALP facilitating learning strategies are an integral part of the assessment tool. The design of the ALP instrument allows the facilitator to easily mark up the descriptors of each of the categories, thus providing a clear illustration of how the learner's performance oscillates during a session. Plotting where the learner is within the learning process guides the facilitator to choose the appropriate ALP facilitating strategy to a level of "the just right challenge" for the learner.

This new instrument, together with its facilitating strategies, is inclusive and therefore can be used with the full spectrum of learners who previously could be excluded from the experience of powered mobility use because of cognitive and behavioral limitations [7,13,17]. The ALP tool is independent of age, degree of cognitive limitation, access method, combinations of additional limitations, and culture. With this approach, more learners with complex and multiple disabilities could be provided with greater opportunities to explore powered mobility use [12-13,16-17,35-36].

Experiences of activity have to be within the individual and the situation; thus, practice in powered wheelchairs needs to take place in real environments $[4,6]$. Future research should take place within community and clinical settings and needs to address the ALP tool on the topics of interrater reliability, implications for implementation, and outcomes of use in various settings.

In addition, the ALP tool needs to be modified in order to assess other types of tool use learning, from simple to complex, for example using a spoon for feeding or using computer software. The content of the ALP tool is dynamic and will need to be modified as a result of future findings.

\section{ACKNOWLEDGMENTS}

\section{Author Contributions:}

Study concept and design: L. Nilsson, J. Durkin.

Ethical approval: L. Nilsson, J. Durkin.

Acquisition of data: L. Nilsson, J. Durkin.

Analysis and interpretation of data: L. Nilsson, J. Durkin.

Drafting of manuscript: L. Nilsson, J. Durkin.

Critical revision of manuscript for important intellectual content:

L. Nilsson, J. Durkin.

Financial Disclosures: The authors have declared that no competing interests exist.

Funding/Support: This material was based on work supported by the Lady Allen of Hurtwood Memorial Trust, London, United Kingdom, which provided a travel grant of $£ 900$ to Dr. Josephine Durkin in January 2009.

\section{REFERENCES}

1. Nilsson L, Nyberg P, Eklund M. Training characteristics important for growing consciousness of joystick-use in people with profound cognitive disabilities. Int $J$ Ther Rehabil. 2010;17(11):588-94.

2. Ranka J, Chapparo C. Occupational Performance Model (Australia). Definition of terms [Internet]. Sydney (Australia): Occupational Performance Network; 2013 [cited 2013 Nov 2]. Available from:

http://www.occupationalperformance.com/definitions/

3. Boisvert R. John Dewey: Rethinking our time. Albany (NY): State University of New York Press; 1998.

4. Cutchin MP. Using Deweyan philosophy to rename and reframe adaptation-to-environment. Am J Occup Ther. 2004;58(3):303-12, discussion 313-16. [PMID:15202628] http://dx.doi.org/10.5014/ajot.58.3.303

5. Butler C, Okamoto GA, McKay TM. Powered mobility for very young disabled children. Dev Med Child Neurol. 1983;25(4):472-74. [PMID:6225687] http://dx.doi.org/10.1111/j.1469-8749.1983.tb13792.x

6. Routhier F, Vincent C, Desrosiers J, Nadeau S. Mobility of wheelchair users: A proposed performance assessment framework. Disabil Rehabil. 2003;25(1):19-34. [PMID:12554389] http://dx.doi.org/10.1080/dre.25.1.19.34

7. Hardy P. Powered wheelchair mobility: An occupational performance evaluation perspective. Aust Occup Ther J. 2004;51:34-42.

http://dx.doi.org/10.1111/j.1440-1630.2004.00413.x

8. Guerette P, Tefft D, Furumasu J, Moy F. Development of a cognitive assessment battery for young children with physical impairments. Infant-Toddler Intervention. 1999;9:169-84.

9. Tefft D, Guerette P, Furumasu J. Cognitive predictors of young children's readiness for powered mobility. Dev Med 
Child Neurol. 1999;41(10):665-70. [PMID:10587042] http://dx.doi.org/10.1017/S0012162299001371

10. Field D. Powered mobility: A literature review illustrating the importance of a multifaceted approach. Assist Technol. 1999;11(1):20-33. http://dx.doi.org/10.1080/10400435.1999.10131982

11. Durkin J. The need for a child led assessment tool for powered mobility users. Technol Disabil. 2002;14(4):163-71.

12. Durkin J. Developing powered mobility with children who have multiple and complex disabilities: Moving forward [dissertation]. [Brighton, UK]: University of Brighton; 2006.

13. Durkin J. Discovering powered mobility skills with children: 'Responsive partners' in learning. Int J Ther Rehabil. 2009;16(6):331-41.

14. Nilsson LM, Nyberg PJ. Driving to learn: A new concept for training children with profound cognitive disabilities in a powered wheelchair. Am J Occup Ther. 2003;57(2):229-33. [PMID:12674317] http://dx.doi.org/10.5014/ajot.57.2.229

15. Nilsson L, Eklund M. Driving to learn. Powered wheelchair training for those with cognitive disabilities. Int $\mathrm{J}$ Ther Rehabil. 2006;13(11):517-27.

16. Nilsson L. Driving to learn. The process of growing consciousness of tool use-a grounded theory of de-plateauing [dissertation]. [Lund, Sweden]: University of Lund; 2007.

17. Nilsson L, Eklund M, Nyberg P, Thulesius H. Driving to learn in a powered wheelchair: The process of learning joystick use in people with profound cognitive disabilities. Am J Occup Ther. 2011;65(6):652-60. [PMID:22214109] http://dx.doi.org/10.5014/ajot.2011.001750

18. Nilsson L, Eklund M, Nyberg P. Driving to Learn in a powered wheelchair: Inter-rater reliability of a tool for assessment of joystick-use. Aust Occup Ther J. 2011;58(6):447-54. [PMID:22111647] http://dx.doi.org/10.1111/j.1440-1630.2011.00983.x

19. Livingstone R. A critical review of powered mobility assessment and training for children. Disabil Rehabil Assist Technol. 2010;5(6):392-400. [PMID:20550464] http://dx.doi.org/10.3109/17483107.2010.496097

20. Glaser B, Strauss A. The discovery of grounded theory: strategies for qualitative research. Chicago (IL): Aldine; 1967.

21. Glaser B. Theoretical sensitivity: Advances in the methodology of grounded theory. Mill Valley (CA): Sociological Press; 1978.

22. Glaser B. Doing grounded theory: Issues and discussions. Mill Valley (CA): Sociology Press; 1998.

23. Nilsson L. Köra för att Lära ${ }^{\mathrm{TM}}$. Att använda och utvärdera en ny arbetsmetod inom kommunens verksamhet för barn, unga och vuxna med utvecklingsstörning [Driving to Learn $^{\mathrm{TM}}$ : To use and evaluate a new intervention in community activities for children, young and adults with intel- lectual disabilities]. Luleå (Sweden): Kommunförbundet Norrbotten, Sweden, Rapportserie FoU Norrbotten nr 54; 2009. Swedish.

24. Svensson E, Nilsson L. Köra för att Lära FoU Habilitering och Hjälpmedel [Driving to learn: Report of the project within the framework of alternative/complementary therapies 2008]. Region Skåne (Sweden): Enkel rapport nr 3; 2009 [cited 2013 Nov 2]. Available from:

https://www.skane.se/public/hab/5-omoss/fou/korta/ kortrapport-2009nr03-engelsk.pdf

25. Lincoln YS, Guba EG. Naturalistic inquiry. Beverly Hills (CA): Sage Publication; 1985.

26. Ayres J. Sensory integration and the child. Los Angeles (CA): Western Psychological Services; 1987.

27. Yerxa EJ. Health and the human spirit for occupation. Am J Occup Ther. 1998;52(6):412-18. [PMID:9612490] http://dx.doi.org/10.5014/ajot.52.6.412

28. Solomon-Rice P, Soto G. Co-construction as a facilitative factor in supporting the personal narratives of children who use augmentative and alternative communication. Comm Disord Q. 2011;32:70-82. http://dx.doi.org/10.1177/1525740109354776

29. Pepper J, Weitzman E, Manolson HA. It takes two to talk: A practical guide for parents to helping children with language delays. Toronto (Canada): Hanen Centre; 1992.

30. Vygotsky L. Mind in society: The development of higher psychological processes. Cambridge (MA): Harvard University Press; 1978.

31. Freire P. Pedagogy of the oppressed. London (England): Penguin;1996.

32. Simpson RC. Smart wheelchairs: A literature review. J Rehabil Res Dev. 2005;42(4):423-36. [PMID:16320139] http://dx.doi.org/10.1682/JRRD.2004.08.0101

33. Krefting L. Rigor in qualitative research: The assessment of trustworthiness. Am J Occup Ther. 1991;45(3):214-22. [PMID:2031523] http://dx.doi.org/10.5014/ajot.45.3.214

34. Guba EG. Criteria for assessing the trustworthiness of naturalistic inqueries. Educ Technol Res Dev. 1981;29(2):75-91.

35. Casey J, Paleg G, Livingstone R. Facilitating child participation through powered mobility. Br J Occup Ther. 2013; 76(3):157-59.

http://dx.doi.org/10.4276/030802213X13627524435306

36. Livingstone R, Paleg G. Practice considerations for the introduction and use of power mobility for children. Dev Med Child Neurol. 2014;56(3):210-21. [PMID:23998510] http://dx.doi.org/10.1111/dmcn.12245

Submitted for publication November 4, 2013. Accepted in revised form February 27, 2014. 
This article and any supplementary material should be cited as follows:

Nilsson L, Durkin J. Assessment of learning powered mobility use-Applying grounded theory to occupational performance. J Rehabil Res Dev. 2014;51(6):963-74. http://dx.doi.org/10.1682/JRRD.2013.11.0237
ResearcherID/ORCID: Lisbeth Nilsson, PhD, OTR: A8370-2012/0000-0001-5988-3192

\begin{tabular}{|c|c|}
\hline $\begin{array}{l}\text { au subussions screened gr } \\
\text { iThenticate }\end{array}$ & ef \\
\hline 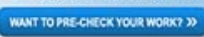 & $\begin{array}{l}\text { CROSSREEF.ORG } \\
\text { THE GITATIOH LINKIHG BACKEONE }\end{array}$ \\
\hline
\end{tabular}


